\title{
Leaf heliotropism in Styrax camporum Pohl from the Brazilian cerrado - distinct gas exchange and leaf structure, but similar leaf temperature and water relations
}

\author{
Gustavo Habermannn ${ }^{1, *}$, Silvia R. Machado ${ }^{2}$, Vandeir F. Guimarães ${ }^{3}$ and João D. Rodrigues ${ }^{2}$ \\ ${ }^{1}$ Universidade Estadual Paulista, Instituto de Biociências, Departamento de Botânica, Av. 24-A, 1515, 13506-900 Rio \\ Claro, SP, Brasil. ${ }^{2}$ Universidade Estadual Paulista, Instituto de Biociências, Departamento de Botânica, C.P. 510, \\ 18618-000 Botucatu, SP, Brasil. ${ }^{3}$ Universidade Estadual do Oeste do Paraná (UNIOESTE), Rua Pernanbuco, 1777, \\ CCA, 85960-000 Mal. Cândido Rondon, PR, Brasil.*Corresponding author: ghaber@rc.unesp.br
}

Received: 23 January 2008; Returned for revision: 28 March 2008; Accepted: 28 April 2008

Styrax camporum is a common shrub species from the cerrado regions of São Paulo State, Brazil. Although its leaves do not have a morphologically delimited pulvinus, the apical leaves are oriented parallel to the sun (paraheliotropic leaves), most notably around noon. Horizontal leaves at the base of shoots are oriented perpendicular to the sun's rays (diaheliotropic leaves). The ecophysiological significance of this is not fully understood. We investigated how paraheliotropism influences daily $\mathrm{CO}_{2}$ assimilation $(A)$ and other gas exchange rates, water relations, leaf temperature $\left(\mathrm{T}_{1}\right)$, and how these relate to leaf structure as assessed by anatomical leaf descriptions. Paraheliotropic leaves had greater $A$ and stomatal conductance $\left(g_{\mathrm{s}}\right)$, which led to greater transpiration rates $(E)$ during most of the day. However, no categorical data proved that these responses were responsible for the lower $\mathrm{T}_{1}$ for vertical leaves, which only occurred at $1100 \mathrm{~h}$ and $1600 \mathrm{~h}$. There was no indication that $\mathrm{Tl}$ influenced $A, E$, or $g_{\mathrm{s}}$. However, diaheliotropic leaves did not assimilate less carbon because of a smaller stomatal aperture. Both leaf types had satisfactory stomatal apertures and the same $g_{s}$ range, resulting in similar intercellular $\mathrm{CO}_{2}$ levels. Paraheliotropic leaves had higher $A$ rates under increased irradiance, suggesting an avoidance of excessive irradiance. Both leaf types had compact spongy parenchyma, representing an increased photosynthetic capacity per unit leaf area. Paraheliotropism in S. camporum does not seem to be related to leaf temperature control, even in the stressful Brazilian cerrado habitat.

Key words: Brazilian savanna, ecophysiology, gas exchange, leaf movements, leaf temperature, photosynthesis, Styracaceae

Heliotropismo foliar em Styrax camporum Pohl, uma espécie do cerrado brasileiro - padrões distintos de trocas gasosas e estrutura foliar, porém com temperatura foliar e relações hídricas similares: Styrax camporum é uma espécie arbustiva comum dos cerrados do Estado de São Paulo, Brasil. Embora suas folhas não tenham pulvino morfologicamente delimitado, as folhas apicais são orientadas paralelamente à incidência da radiação solar (folhas paraheliotrópicas), especialmente às $1200 \mathrm{~h}$. Folhas horizontais estáticas das partes basais dos ramos são orientadas perpendicularmente aos raios solares (folhas diaheliotrópicas). O significado ecofisiológico do fenômeno não foi ainda completamente elucidado. Investigou-se como o paraheliotropismo influencia a assimilação diária de $\mathrm{CO}_{2}(A)$ e outras taxas de trocas gasosas, relações hídricas, temperatura foliar $\left(\mathrm{T}_{\mathrm{f}}\right)$ e suas relações com a estrutura da folha, avaliada por suas descrições anatômicas. Folhas paraheliotrópicas apresentaram maiores $A$ e condutância estomática $\left(g_{\mathrm{s}}\right)$, o que levou à maior taxa de transpiração $(E)$ durante grande parte do dia. Todavia, não houve dados categóricos assegurando que estas respostas tenham determinado menor $T_{f}$ para as folhas verticais, que ocorreu apenas às 1100 e $1600 \mathrm{~h}$. Não houve nenhuma indicação de que $\mathrm{T}_{\mathrm{f}}$ influenciou $A, E$ ou $g_{\mathrm{s}}$. Entretanto, folhas diaheliotrópicas não assimilaram menos carbono por causa de estômatos mais fechados. Ambos os tipos foliares atingiram abertura estomática satisfatória e a 
mesma zona de resposta de $g_{\mathrm{s}}$ resultou em concentrações de $\mathrm{CO}_{2}$ intercelular similares. Folhas paraheliotrópicas tiveram maior $A$ sob elevadas irradiâncias, sugerindo evitação à elevada irradiância. Em ambos tipos de folhas, observou-se parênquima esponjoso compacto, representando maior capacidade fotossintética por unidade de área foliar. O paraheliotropismo de $S$. camporum não parece estar relacionado ao controle da temperatura foliar, mesmo no estressante hábitat do cerrado Brasileiro.

Palavras-chave: cerrado Brasileiro, ecofisiologia, fotossíntese, movimentos foliares, Styracaceae, temperatura foliar, trocas gasosas

\section{INTRODUCTION}

The cerrado, or Brazilian savanna, comprises a vertically structured mosaic of grassland, scrubland, and dense woodland physiognomies (Oliveira and Marquis, 2002; Ferreira et al, 2003). This biome demonstrates a conspicuous seasonal contrast between the dry (April to September) and rainy (October to March) seasons. The soils of these areas are ancient, deep, sandy, acid, poor in organic matter and mineral salts, and high in aluminum (Oliveira and Marquis, 2002). Water deficit, soil conditions, and fire have imposed enormous environmental pressures on this biome (Ferreira et al, 2003).

As in other savanna-type ecosystems, cerrado plants are subjected to high irradiance stress and respond with several general strategies (Oliveira and Marquis, 2002), including heliotropic leaf adjustments (Rodrigues and Machado, 2006). Heliotropism can be divided into two classes: (i) diaheliotropism, in which the leaf lamina become oriented at an angle perpendicular to incoming light; and (ii) paraheliotropism, where leaf lamina orient parallel to the light (Koller, 1986, 1990; Liu et al., 2007). Light interception is maximized by diaheliotropism and minimized by paraheliotropism (Koller 1986, 1990; Bielenberg et al., 2003; Pastenes et al., 2005). However, under natural conditions, some solar-tracking plants can also move their leaves to avoid full exposure to sunlight, minimizing heating and water stress (Caldas et al., 1997). This reduces transpiration rates (Forseth and Ehleringer, 1982) and helps to maintain leaf temperatures near the photosynthetic optimum (Bielenberg et al., 2003; Pastenes et al., 2005) in addition to reducing the potential for photoinhibition (Pastenes et al., 2005). Heliotropic leaf movements are induced by blue wavelengths (Volgemann and Björn, 1983; Sherriff and Ludlow, 1985; Koller, 1986) and heliotropic leaves orient themselves in response to vectorial light (Koller, 1986), but maintain a horizontal position under diffuse light (Sherriff and Ludlow, 1985).

In spite of the putative importance of the leaf adjustments to photosynthetic performance in the environmental conditions of the cerrado, evidence for this seems to be based solely on Pterodon pubescens, a woody legume native to the Central Brazilian region. In this plant, the paraheliotropic movement of leaflets maintains an elevated rate of photochemical reactions under drastically reduced irradiance (Caldas et al., 1997).

In a previous study of Styrax camporum, basal leaves were seen to be diaheliotropic, whereas apical leaves were diaheliotropic early in the morning, but gradually changed to a paraheliotropic orientation at midday (Machado, 1991). In this paper, we hypothesized that, under natural conditions, the paraheliotropic leaves of $S$. camporum have advantageous daily $\mathrm{CO}_{2}$ assimilation rates and water relations and cooler lamina temperatures compared to those of the static diaheliotropic leaves. Leaf gas exchange, leaf water potential, and relative water content (RWC) were therefore measured in solar tracking and non-tracking leaves of S. camporum. Anatomical and ultra-structural leaf analyses were also performed as a framework for the functional studies.

\section{MATERIAL AND METHODS}

Plant material and samplings: The study was conducted on adult plants of Styrax camporum Pohl. from a cerrado area characterized by scattered trees and shrubs and a large proportion of grassland ("closed field") in the municipality of Botucatu ( $22^{\circ} 51^{\prime} \mathrm{S}, 48^{\circ} 26^{\prime} \mathrm{W}$ ), São Paulo State, Brazil. Vouchers were deposited at the BOTU Herbarium of the Department of Botany at the São Paulo State University (UNESP).

Five individual plants between 1.5 and $2 \mathrm{~m}$ tall were

Braz. J. Plant Physiol., 20(1):71-83, 2008 
used. Plants were completely leafy at the beginning of the fall season on April 20 ${ }^{\text {th }}, 2000$, when measurements were taken. Leaves were numbered from the apex to the base of each branch, using three branches per plant. The youngest fully-expanded leaves (leaf number 3 or 4 ) were considered paraheliotropic leaves, whereas mature leaves (leaf number 9, 10, or 11) were diaheliotropic.

Light and electron microscopy: For light microscopy, samples (ca. $3 \mathrm{~mm}^{2}$ ) from the middle region of the para- and diaheliotropic leaves were fixed in FAA (formalin-acetoalcohol 50), dehydrated in an ethyl series, embedded in glycolmethacrylate historesin (Gerrits, 1991), and sectioned with a rotary microtome. The sections (3-5 $\mu \mathrm{m})$ were stained with $0.05 \%$ toluidine blue solution (O'Brien et al., 1964) and mounted in Permount. Freehand sections obtained from fresh leaves were stained with safranin and astra blue (Bukatsch, 1972); with ruthenium red (Jensen, 1962) to detect pectin; Sudan IV for lipids (Johansen, 1940); acid phloroglucin (Sass, 1951) for lignin; iodine zinc chloride for cellulose, and ferric chloride for phenolic substances (Johansen, 1940). For stomatal density (stomata $\mathrm{mm}^{-2}$ ) determinations on the abaxial leaf surface, paradermal freehand sections were sliced with razor blades and counted using a light microscope.

For scanning electron microscopy (SEM), samples were fixed in glutaraldehyde $(2.5 \%$ with $0.1 \mathrm{M}$ phosphate buffer, at $\mathrm{pH} 7.3$; overnight at $4{ }^{\circ} \mathrm{C}$ ), dehydrated in a graded acetone series, dried to the critical point, mounted on aluminum stubs, gold-coated and examined with a Phillips 515 scanning electron microscope at $20 \mathrm{kV}$.

For transmission electron microscopy, samples were fixed in glutaraldehyde $(2.5 \%$ with $0.1 \mathrm{M}$ phosphate buffer, at $\mathrm{pH} 7.3$; for $6-12 \mathrm{~h}$ at $4^{\circ} \mathrm{C}$ ); post-fixed with $1 \%$ osmium tetroxide, in the same buffer, for $2 \mathrm{~h}$ at room temperature; dehydrated in a graded series of ethanol solutions; and embedded in Araldite resin. Ultrathin sections were contrasted with uranyl acetate and lead citrate. Sections were observed on a Philips CM 100 transmission electron microscope at $80 \mathrm{kV}$.

Physiological measurements: Gas exchange was measured with a closed-system portable infrared gas analyzer (LI-6200, LI-COR, Lincoln, Nebraska, USA). Rates of net $\mathrm{CO}_{2}$ assimilation $(A)$ and transpiration $(E)$, stomatal conductance $\left(g_{\mathrm{s}}\right)$, and intercellular $\mathrm{CO}_{2}\left(C_{\mathrm{i}}\right)$ were determined by the LI-6200 data analysis program, which uses the Von Caemmerer and Farquhar (1981) general gasexchange equations. Water-use efficiency (WUE, $A / E$ ) and intrinsic water use efficiency (IWUE, $A / g_{\mathrm{s}}$ ) were also calculated. The leaf temperature $\left(\mathrm{T}_{1}\right)$ was obtained with a thermocouple inside the LI-6200 cuvette $\left(0.25 \mathrm{dm}^{3}\right)$, which also had an external quantum sensor that was used to measure the photosynthetic photon flux (PPF) intercepted by leaves.

The leaf water potential at $0600 \mathrm{~h}\left(\Psi_{\mathrm{pd}}\right)$ and $1500 \mathrm{~h}$ $\left(\Psi_{\mathrm{md}}\right)$ were measured by the pressure chamber method (Kaufmann, 1968), with a DIK-7000 (Daiki Rika Kogyo, Tokyo, Japan) pressure chamber.

For $\Psi_{w}$ and leaf gas-exchange measurements, an average of three paraheliotropic leaves and three diaheliotropic leaves were assessed for each of the five plants (replicates).

The relative leaf water content (RWC) was assessed through five para- and diaheliotropic leaf discs per replication. This value was calculated as RWC (\%) = $[(\mathrm{FW}-\mathrm{DW}) /(\mathrm{TW}-\mathrm{DW})] \times 100$, where $\mathrm{FW}$ is the fresh weight, TW is the turgid weight after rehydrating samples for $24 \mathrm{~h}$ into $100-\mathrm{mL}$ dark glass bottles (for photosynthesis inhibition) with a $0.01 \mathrm{M} \mathrm{KCN}$ solution (for respiration inhibition), and DW is the dry weight after oven-drying discs at $60^{\circ} \mathrm{C}$ for $48 \mathrm{~h}$ (Barrs and Weatherley, 1962). After leaf sampling, FW was immediately obtained (gravimetrically) at the experimental site. The RWC and leaf gas-exchange variables were determined at $0900 \mathrm{~h}$, $1100 \mathrm{~h}, 1400 \mathrm{~h}$ and $1600 \mathrm{~h}$.

Statistical analyses: Five $S$. camporum individuals were randomly selected in an area of one hectare. Leaf gasexchange variables $\left(A, E, g_{\mathrm{s}}, C_{\mathrm{i}}, \mathrm{T}_{1}\right.$, WUE and IWUE), RWC, and $\Psi_{\mathrm{w}}$ were calculated (mean and standard deviation) were subjected to one-way analysis of variance (ANOVA) followed by Tukey's test $(P \leq 0.05)$.

\section{RESULTS}

The abaxial surface of diaheliotropic leaves of $S$. camporum were densely covered with stellate trichomes (Figures 1A,B), whereas the adaxial surface was glabrous, shiny, and characterized by prominent epicuticular striae (Figures 1A-C). In paraheliotropic leaves, the stellate-hair indumentum was seen on both surfaces of the leaf blade (Figure 1D). 
Anatomical features of $S$. camporum leaves include elevated stomata distributed in clusters inside slight crypts (Figure 1E), which are covered by stellate trichomes (Figure 1F). These depressions are located in the intercostal areas on the leaf blade's abaxial surface. There are $950 \pm 30$ stomata per $\mathrm{mm}^{2}$ on the abaxial surfaces of both leaf types. Each stoma has ring-like protuberances of wax substances over the pore, delimiting the front cavity above the aperture, which results in an outer stomatal ledge (Figure 1E) with a dense pectin network (Figures 1G,H). In cross-section, the epidermis of the adaxial surface is formed by tall, tetragonal cells (Figures 1I,J), in which both the outer and inner periclinal walls are thick and rich in pectic substances. The thick cuticle has two distinct layers: a thin outer layer, constituted by cutin that is only detected by the Sudan IV test, and a thick inner stratum, formed by a dense pectin network (Figure $1 \mathrm{~K}$ ), which is detected by the ruthenium red test. Mesophyll tissues are differentiated into a unistratified palisade and a two- to three-layered spongy chlorenchyma (Figure 1I); these cells have numerous wall ingrowths, which develop into slit-like gas spaces within their apparent infolds (Figure 1L). Such cells are thin-walled and possess a peripheral cytoplasm with numerous chloroplasts and a single central vacuole that can be translucent or dense if it is filled with phenolic compounds (Figures 2A,B). Anticlinal cell walls contain well-developed plasmodesmata (Figure 2C).

The vascular system in the mesophyll is composed of collateral bundles surrounded by bundle sheath cells, which extend to the adaxial epidermis (Figure 2D). In paraheliotropic leaves, the parenchymatous bundle sheath cells and their extensions are thin-walled (Figure $2 \mathrm{E})$, but in diaheliotropic leaves, the parenchymatous bundle sheath cells have thickened, sclerified walls (Figure 2D). Prismatic crystals of calcium oxalate occur in the bundle sheath cells.

Along the revolute leaf margins, the epidermal cells are elongated and the chlorenchyma cells are irregular in shape (Figure 2F). These cells present sinuous and thickened walls. The outer periclinal epidermal cell wall is covered by a very thick cuticle with deposits of pectic substances (Figure $2 \mathrm{G})$, as identified by the ruthenium red test.

The midvein is dorsiventral and has narrow and elongated adaxial epidermal cells, whereas the abaxial cells are smaller and irregular in shape. Parenchyma cells that are lacking in chloroplasts and angular collenchyma are more developed in paraheliotropic (Figure $2 \mathrm{H}$ ) than in diaheliotropic leaves (Figure 2I). The vascular tissue is surrounded by a thick ring of sclerenchymatous cells in the diaheliotropic leaves (Figure 2I).

The rate of $A$ was significantly higher for paraheliotropic leaves than for diaheliotropic leaves at $0900 \mathrm{~h}, 1100 \mathrm{~h}$ and $1400 \mathrm{~h}$, but the rates of $A$ were similar at the end of the day (Figure $3 \mathrm{~A}$ ). The $g_{\mathrm{s}}$ and $E$ followed almost the same response pattern (Figures 3B,C), with paraheliotropic leaves having higher values. These leaves showed higher $C_{i}$, but only at $0900 \mathrm{~h}$ (Figure 3D). With regard to WUE, it was essentially the same until $1600 \mathrm{~h}$, when paraheliotropic leaves assimilated more carbon per unit of water lost (Figure $3 \mathrm{E})$. The IWUE $\left(A / g_{\mathrm{s}}\right)$ was higher for paraheliotropic leaves at $0900 \mathrm{~h}$ and $1600 \mathrm{~h}$, and was similar between leaf types at $1100 \mathrm{~h}$ and $1400 \mathrm{~h}$ (Figure 3F).

Figure 4 shows that paraheliotropic leaves have some tendency to respond with greater $A, E$, and $g_{\mathrm{s}}$ as the vapor pressure deficit VPD increases during the day, whereas in diaheliotropic leaves these variables seem to be unresponsive to changing VPD. In the same way, $A$ of paraheliotropic leaves improved (responded with higher values) from a rise in $g_{\mathrm{s}}$ (Figure 5A,B); the same was true for $E$ (Figure 5C,D). In contrast, $C_{\mathrm{i}}$ was not dependent on stomatal aperture (Figure 5E,F).

Neither $E$ nor $g_{\mathrm{s}}$ determined the $\mathrm{T}_{1}$ of paraheliotropic leaves (Figure 6A,C), which was statistically lower than in the diaheliotropic leaves at $1100 \mathrm{~h}$ and $1600 \mathrm{~h}$ (Figure 7B). During most of the day, both leaf types had the same range of $E$ and $g_{\mathrm{s}}$, with $\mathrm{T}_{1}$ around $35^{\circ} \mathrm{C}$ (Figure 6A-D). The $\mathrm{T}_{1}$ did not show any clear influence on $A$ of either leaf type (Figure 6E,F), which was maximal at $35^{\circ} \mathrm{C}$. For paraheliotropic leaves, greater PPF resulted in higher $A$ rates, whereas diaheliotropic leaves did not change their rate of $A$ based on the time of day or on PPF (Figure 6G,H).

Both $\Psi_{\mathrm{pd}}$ or $\Psi_{\mathrm{md}}$ and the RWC were similar for both leaf types (Figure 7A,C).

\section{DISCUSSION}

The anatomical features of $S$. camporum leaves include revolute borders, stellate trichomes, thick cuticles, stomata inside crypts on the abaxial leaf surface, compactly-arranged chlorenchyma cells, and bundlesheath extensions. Many of these features were described for Styracaceae species from the Mediterranean 

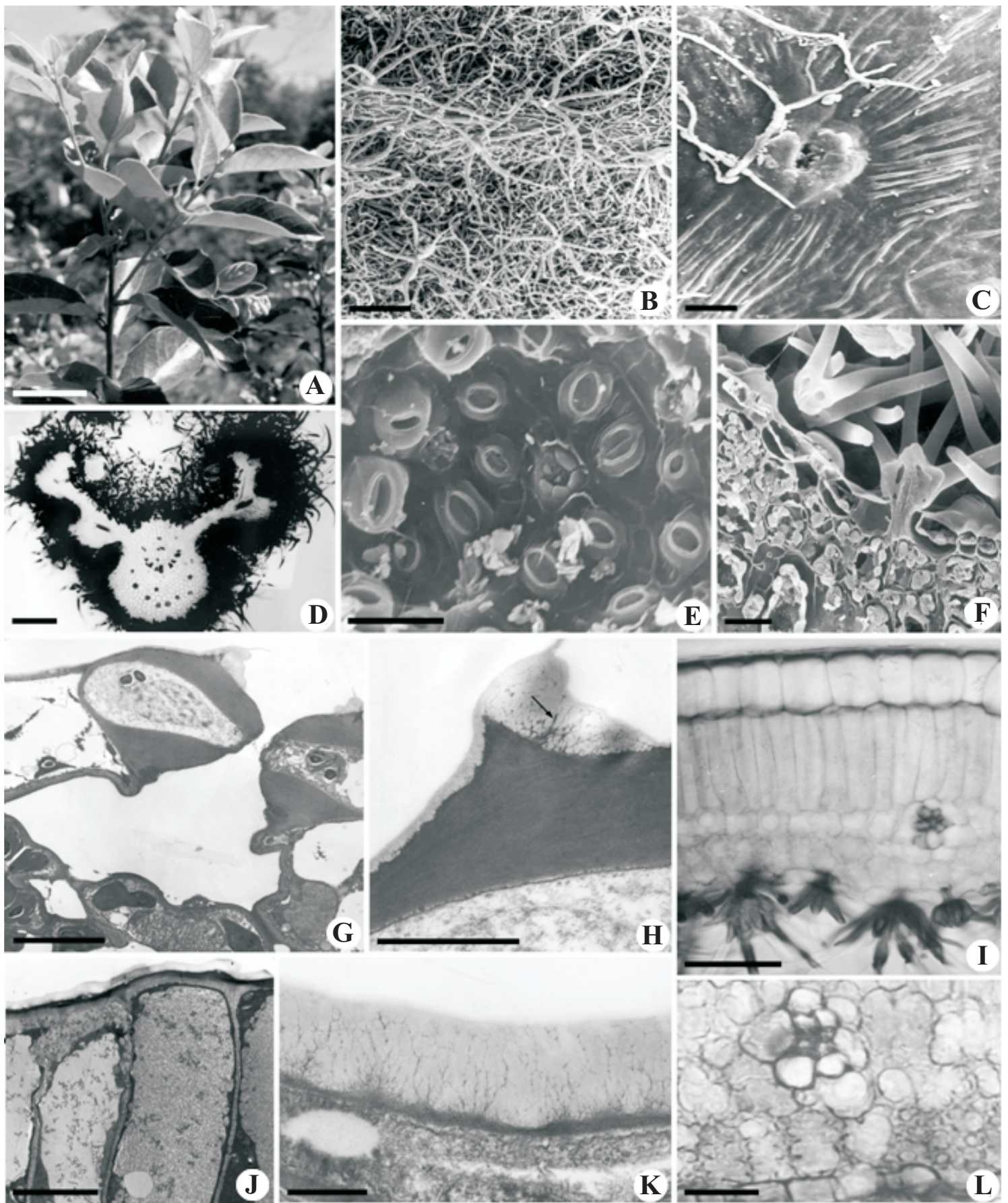

Figure 1. Aspects of the paraheliotropic and diaheliotropic leaves of Styrax camporum. A. Vegetative twig of Styrax camporum showing apical paraheliotropic leaves and basal diaheliotropic leaves. B. Leaf abaxial surface covered with stellate pubescence. C. Leaf adaxial surface with epicuticular striae. D. Paraheliotropic leaf covered with dense pubescence. E. Cluster of stomata in crypts. F. Cross-section of a leaf blade showing salient stomata covered with stellate hairs. G. Stomate cross-section showing outer stomatal ledge (arrows). H. Outer stomatal ledge. Notice the network (arrow) of pectic substances. I. Cross-section of a leaf blade showing adaxial epidermal surface and dorsiventral mesophyll. J. Pectic substance accumulation between the cuticle and the outer epidermal cell wall. K. Cuticle detail showing a network of pectic substances. L. Cross-section of a leaf blade showing compact spongy parenchyma. Bars $=90 \mu \mathrm{m}(\mathbf{B}) ; 60 \mu \mathrm{m}$ (C); $200 \mu \mathrm{m}$ (D); $20 \mu \mathrm{m}(\mathbf{E}, \mathbf{F}) ; 3 \mu \mathrm{m}(\mathbf{G}) ; 1 \mu \mathrm{m}(\mathbf{H}) ; 50 \mu \mathrm{m}(\mathbf{I}) ; 5 \mu \mathrm{m}(\mathbf{J}) ; 0,25 \mu \mathrm{m}(\mathbf{K}) ; 10 \mu \mathrm{m}(\mathbf{L})$. 

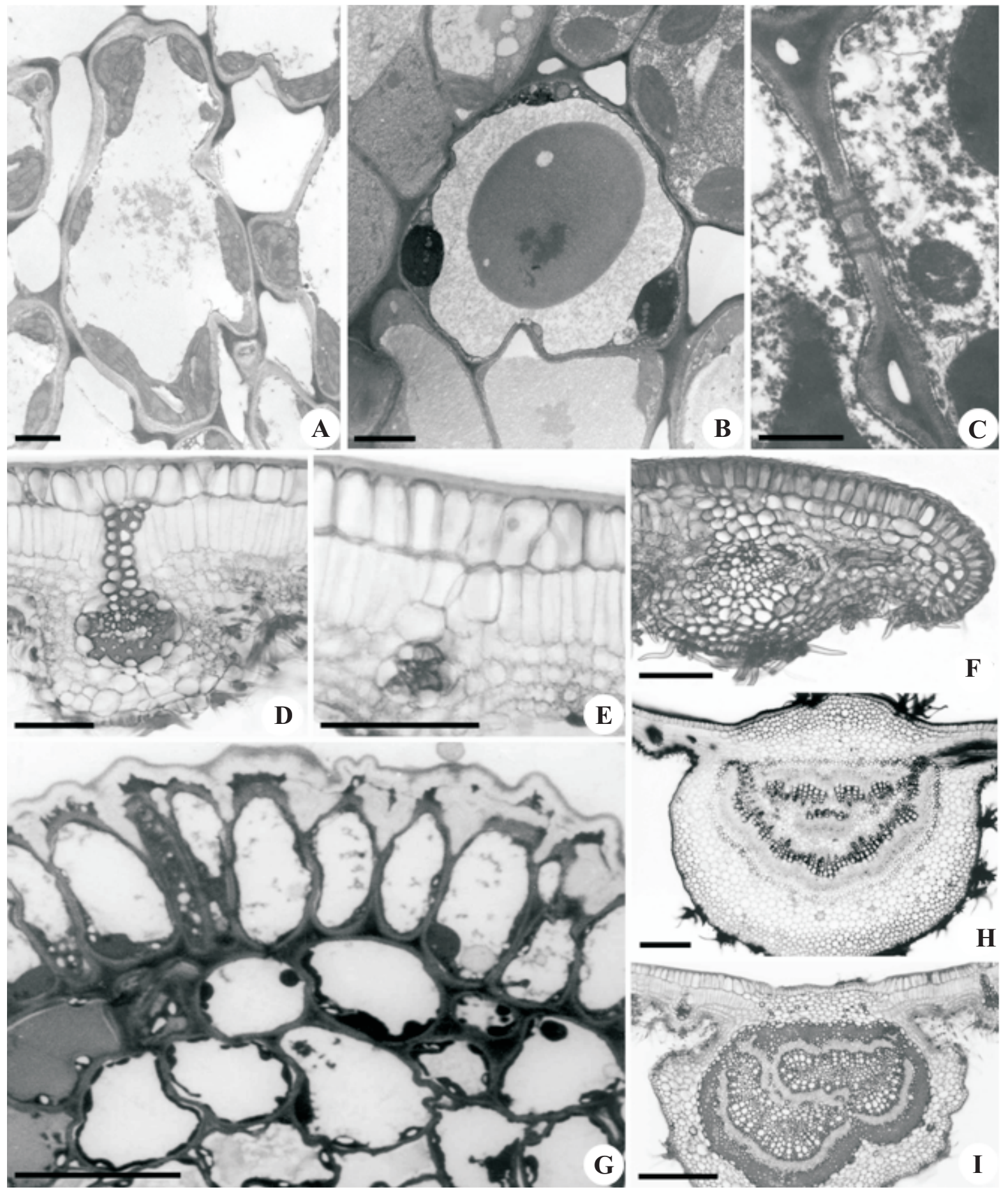

Figure 2. Aspects of paraheliotropic and diaheliotropic leaves of Styrax camporum. A. Spongy parenchyma cell with prominent chloroplasts. B. Spongy parenchyma cell with heterogeneous material in the vacuole. C. Plasmodesmata in the anticlinal walls of the epidermal cells. D. Sclerenchyma extension bundle sheath in a diaheliotropic leaf. E. Parenchyma extension bundle sheath in a paraheliotropic leaf. F. Revolute leaf border. G. Revolute leaf border, detail. Notice the dense substance between the very thick cuticle and the outer periclinal epidermal cell wall. H. Midvein cross-section of the paraheliotropic leaf. I. Midvein cross-section of the diaheliotropic leaf. Notice the well-developed sclerenchyma ring around the phloem. Bars $=0.5 \mu \mathrm{m}(\mathbf{A}, \mathbf{B}, \mathbf{C}) ; 0.2 \mu \mathrm{m}(\mathbf{D}) ; 50 \mu \mathrm{m}(\mathbf{E}, \mathbf{F}) ; 30 \mu \mathrm{m}(\mathbf{G}) ; 200 \mu \mathrm{m}(\mathbf{H}, \mathbf{I})$. 

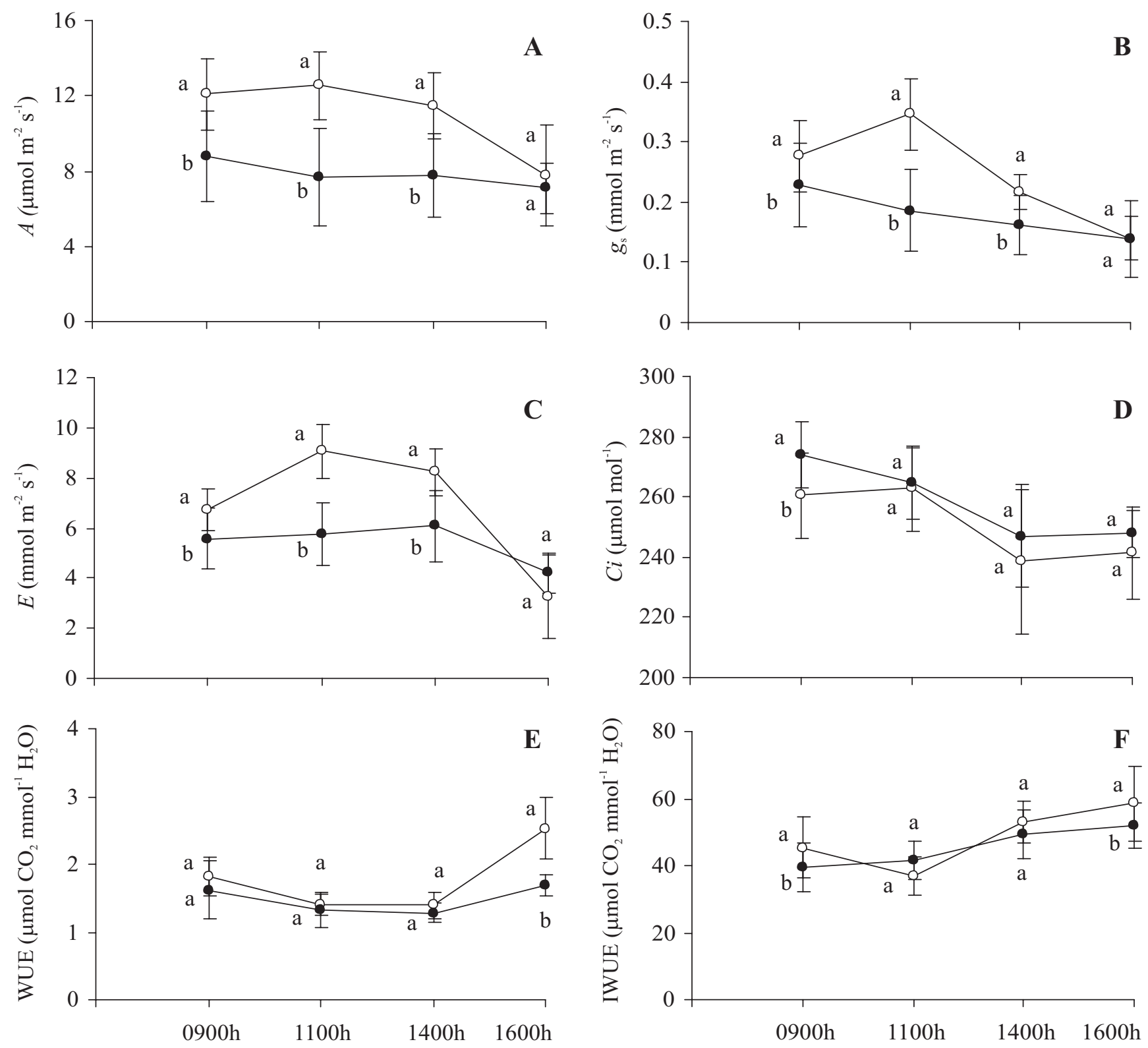

Figure 3. Daily variations in $\mathrm{CO}_{2}$ assimilation (A), stomatal conductance $(\mathbf{B})$, transpiration rates $(\mathbf{C})$, intercellular $\mathrm{CO}_{2}$ (D), water-use efficiency $(A / E)(\mathbf{E})$ and intrinsic water-use efficiency $\left(A / g_{\mathrm{s}}\right)(\mathbf{F})$ of para- $(O)$ and dia- $(\bullet)$ heliotropic leaves of Styrax camporum in the field, on April 20 ${ }^{\text {th }} 2000$, in Botucatu, southeastern Brazil. For each time point, same letters indicate lack of statistical significance between leaves by the Tukey test $(P>0.05)$. (Vertical bars $=\mathrm{SD})$.

region and have been associated with adaptation to xeric environments (Schadel and Dickson, 1979).

It is unlikely that the $S$. camporum plants evaluated here were facing a soil water deficit on April 20 2000. Chaves et al. (2002) reaffirmed some of her previous results, adding very convincing data showing that for many species photosynthetic capacity is only decreased at leaf RWC around $60 \%$. The RWC of both leaf types remained around $86 \%$, which is suggestive of wellhydrated leaves. Typical $A$ responses for $S$. camporum were found to be around $4 \mu \mathrm{mol} \mathrm{m} \mathrm{m}^{-2} \mathrm{~s}^{-1}$, with great stomatal restriction on a drought season day in August, 2006 (data not published). Prior et al. (1997) described $\Psi_{\mathrm{pd}}$ $<-0.5 \mathrm{MPa}$ as the initial water deficit transitional stage for 

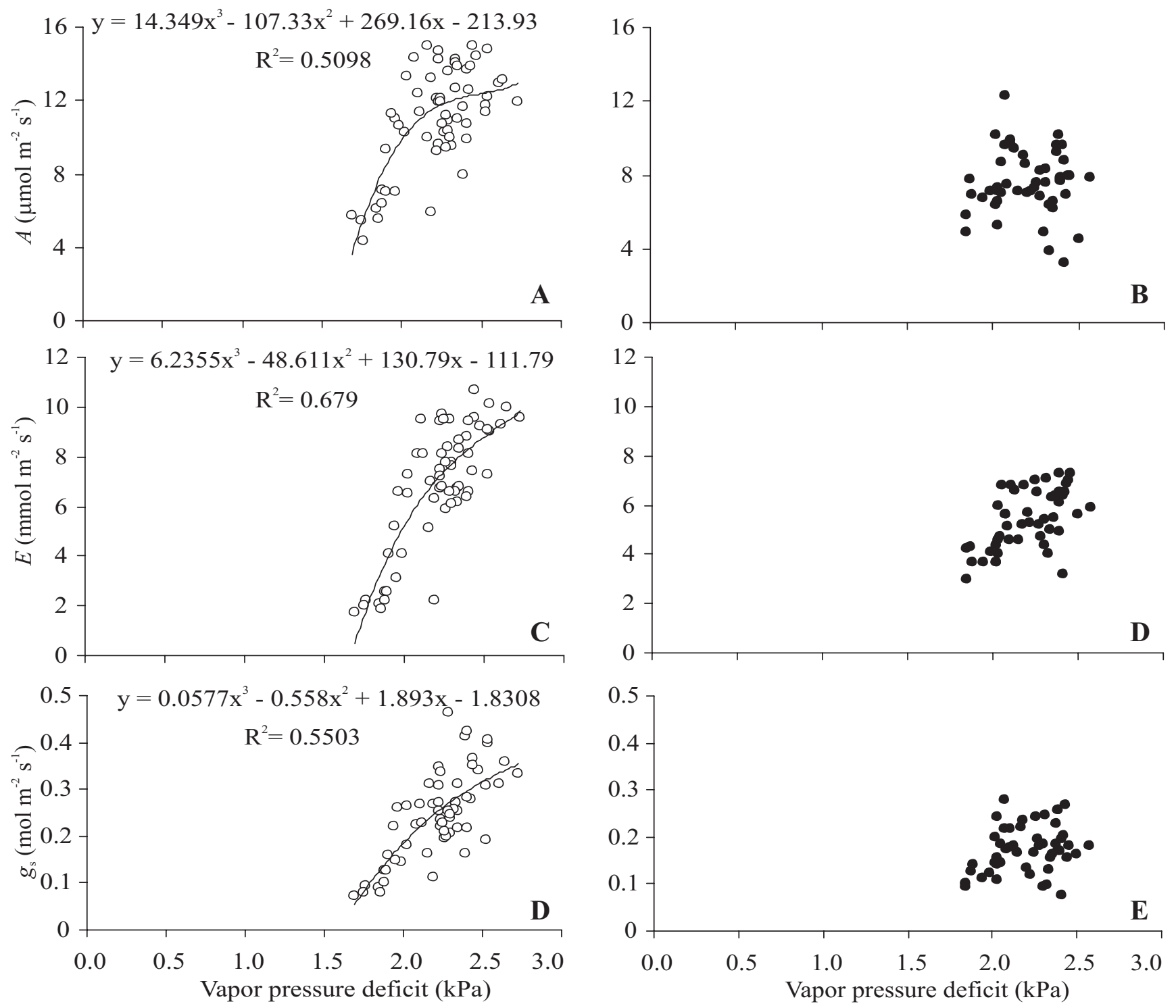

Figure 4. Individual readings (replicates) of $\mathrm{CO}_{2}$ assimilation $(\mathbf{A}, \mathbf{B})$, transpiration rates $(\mathbf{C}, \mathbf{D})$ and stomatal conductance $(\mathbf{E}, \mathbf{F})$ in relation to the VPD for para- (O) and dia- $(\bullet)$ heliotropic leaves of Styrax camporum in the field, on April $20^{\text {th }}$ 2000 , in Botucatu, southeastern Brazil. Only regression equations with $R^{2}>0.5$ are shown.

woody species from northern Australian savannas, but our data show $\Psi_{\text {pd }}>-0.3 \mathrm{MPa}$ for both leaf types. Moreover, S. camporum that are $2.5 \mathrm{~m}$. tall may have roots that reach more than $12 \mathrm{~m}$ deep (Machado et al., 1997). Thus, good leaf hydration may explain the constant and high $A$ values during the day, especially for diaheliotropic leaves. This is in agreement with Prado et al. (2004) who found $8.6 \mu \mathrm{mol} \mathrm{m} \mathrm{m}^{-2} \mathrm{~s}^{-1}$ of net photosynthesis for $S$. camporum during the wet season. However, paraheliotropic leaves seemed to benefit from the vertical position, with higher $A$ at $0900 \mathrm{~h}, 1100 \mathrm{~h}$, and $1400 \mathrm{~h}$.

Paraheliotropism avoids leaf heating (Bielenberg et al., 2003; Pastenes et al., 2005) and reduces transpiration rates (Forseth and Ehleringer, 1982). Pastenes et al. (2005) observed that restrained horizontal leaves of Phaseolus vulgaris intercepted more irradiance and had higher $A$, in spite of having lower $g_{s}$. Our data show opposite results: paraheliotropic leaves had greater $g_{\mathrm{s}}$, which led to greater $E$ rates for most of the day, but there were no categorical data to confirm that these responses resulted in lower $\mathrm{T}_{1}$ 

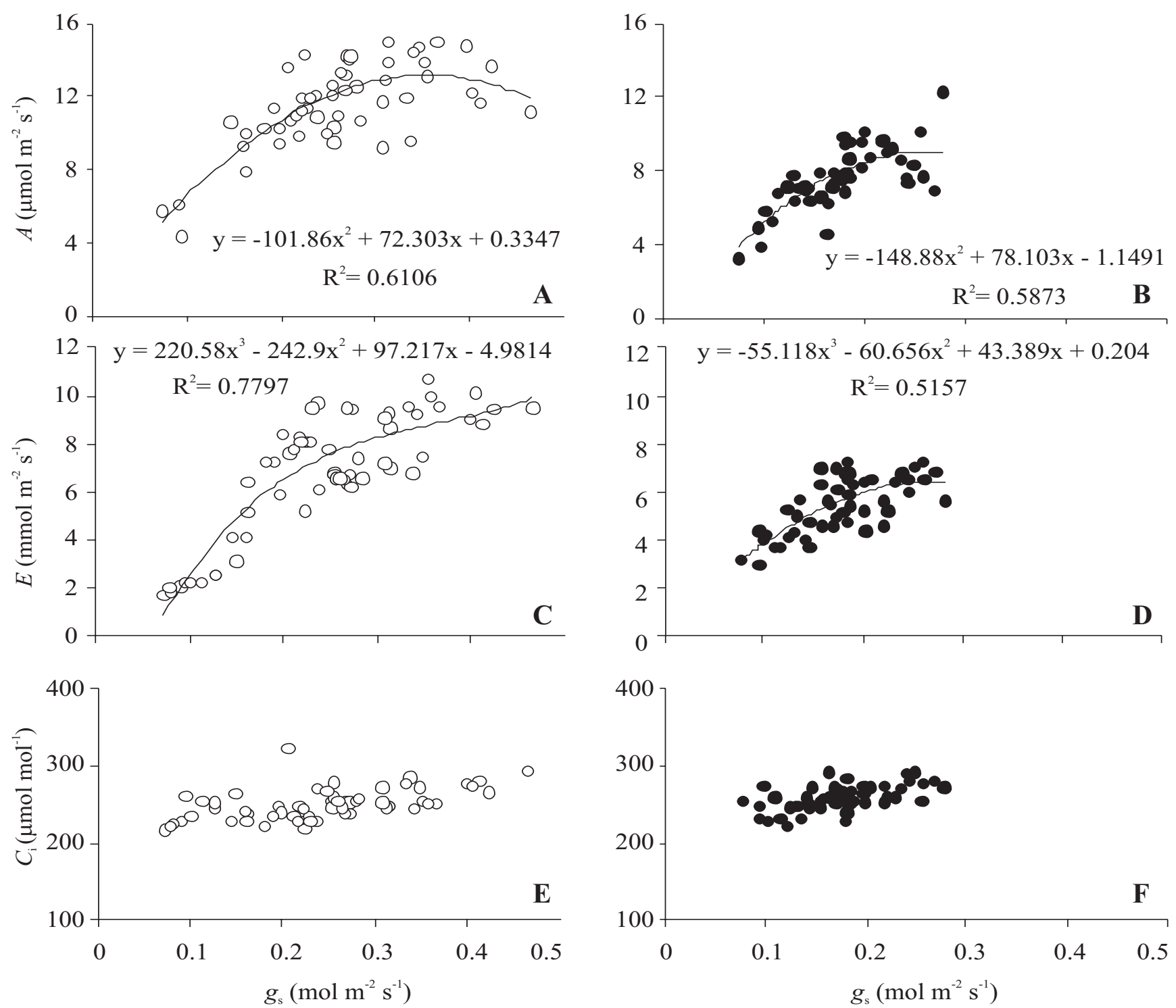

Figure 5. Individual readings (replicates) of $\mathrm{CO}_{2}$ assimilation $(\mathbf{A}, \mathbf{B})$, transpiration rates $(\mathbf{C}, \mathbf{D})$ and intercellular $\mathrm{CO}_{2}(\mathbf{E}, \mathbf{F})$ in relation to the stomatal conductance for para- (O) and dia- $(\bullet)$ heliotropic leaves of S. camporum in the field, on April $20^{\text {th }} 2000$, in Botucatu, southeastern Brazil. Only regression equations with $R^{2}>0.5$ were shown.

for vertical leaves. Moreover, there was no direct indication that $\mathrm{T}_{1}$ influenced $A, E$ or $g_{\mathrm{s}}$, and, additionally, for paraheliotropic leaves, $g_{\mathrm{s}}$ and $E$ became higher as VPD increased, whereas VPD caused no such response on diaheliotropic leaves, contrarily to what is expected from laboratory and field measurements covering a wide range of species in which it has been demonstrated that $g_{s}$ decreases with increasing VPD (Schulze and Hall, 1982; Grantz, 1990). Nevertheless, Meinzer et al. (1999) presented some data from Sclerolobium paniculatum, a solar-tracking woody cerrado plant that showed a positive correlation between $g_{\mathrm{s}}$ and VPD, similar to our results for paraheliotropic leaves. They observed that $\mathrm{T}_{1}$ was markedly lower $\left(4^{\circ} \mathrm{C}\right)$ than air temperature at midday, as compared with other species that had a negative $g_{\mathrm{s}} \mathrm{x}$ VPD correlation. This caused a large difference between leaf-to-air VPD and air VPD, partly explaining the positive correlation. We have also seen this positive correlation for $S$. camporum on a drought season day in August, 2006 (data not published). However, in the present study, 

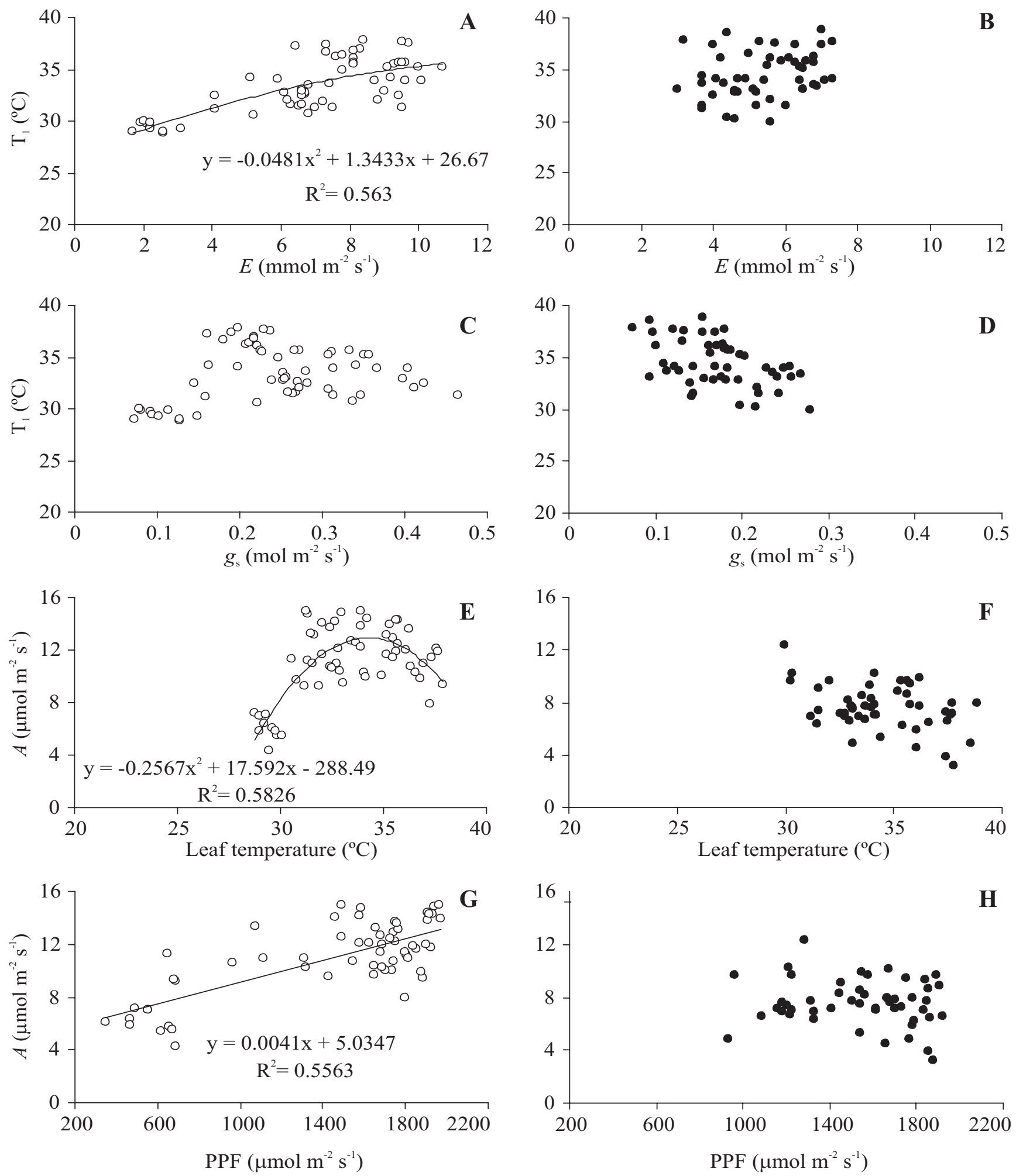

Figure 6. Individual readings (replicates) of leaf temperature in relation to the transpiration rate $(\mathbf{A}, \mathbf{B})$ and stomatal conductance $(\mathbf{C}, \mathbf{D})$; and $\mathrm{CO}_{2}$ assimilation in relation to leaf temperature $(\mathbf{E}, \mathbf{F})$ and photosynthetic photon flux $(\mathbf{G}, \mathbf{H})$ for para- (O) and dia- $(\bullet)$ heliotropic leaves of Styrax camporum in the field, on April $20^{\text {th }} 2000$, in Botucatu, southeastern Brazil. Only regression equations with $R^{2}>0.5$ were shown. 

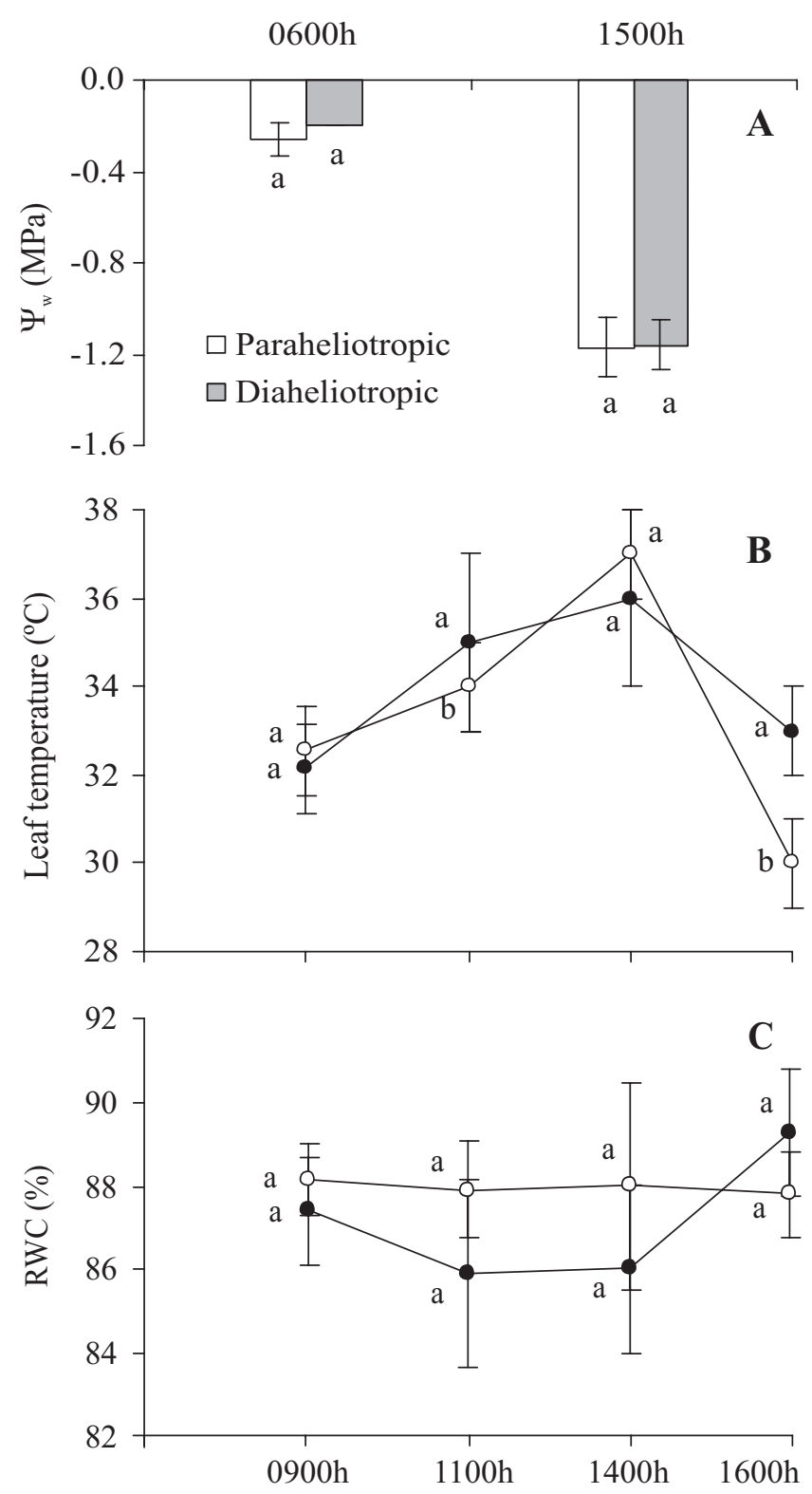

Figure 7. Predawn and midday leaf water potential (A), and daily variations in the temperature $(\mathbf{B})$ and relative water content $(\mathbf{C})$ of para- $(0)$ and dia- $(\bullet)$ heliotropic leaves of $S$. camporum in the field, on April $20^{\text {th }} 2000$, in Botucatu, southeastern Brazil. Same letters indicate lack of statistical significance between leaves by the Tukey test $(P>0.05)$. $($ Vertical bars $=\mathrm{SD})$.

there was no conspicuous difference between vertical and horizontal $\mathrm{T}_{1}$. Moreover, the higher $E$ rates and $g_{\mathrm{s}}$ for paraheliotropic leaves can not be attributed to stomatal density differences, because both leaf types had the same number of stomata per $\mathrm{mm}^{2}$.
Although $A$ rates of paraheliotropic leaves increased with a rise in $g_{s}$, diaheliotropic leaves did not assimilate less carbon because of decreased stomatal aperture. Both leaf types had satisfactory $\left(0.2-0.3 \mathrm{mmol} \mathrm{m}^{-2} \mathrm{~s}^{-1}\right)$ stomatal apertures; moreover, the same $g_{s}$ range resulted in similar $C_{\mathrm{i}}$ for both leaf types (Figures 3D, 5E and 5F). Thus, paraheliotropic leaves have a higher photosynthetic capacity per unit leaf area, if compared to diaheliotropic leaves.

The direct effect of paraheliotropism as shown by Bielenberg et al. (2003) and Liu et al. (2007) is a reduction in the PPF intercepted by the leaf, which other studies have demonstrated lower leaf temperature (Pastenes et al., 2005) and improved water status (Meinzer et al., 1999). It has been well accepted that leaf movement in parallel to irradiance is an action that effectively minimizes photoinhibition. When water stress occurs with high light and high temperatures, it exerts some of its effect through oxidative damage. This may be associated with an increase in the Mehler reaction, which contributes to superoxide production, increasing the damage to photosystem II (PSII) (Chaves et al., 2002). Pastenes et al. (2005) found a clear protective effect of paraheliotropism in water-stressed leaves of $P$. vulgaris with higher recovery of the maximum quantum yield and higher values of photochemical quenching of chlorophyll fluorescence. In well-watered plants, those authors found higher D1 protein concentrations (lower degradation) in PSII when leaves were not horizontally restrained. Thus, well-documented findings support the theory that $S$. camporum paraheliotropic leaves had a lower irradiance load, with lower photoinhibition, partly explaining the higher rates of $\mathrm{CO}_{2}$ assimilation. In the present study, leaf movement did not substantially change $\mathrm{T}_{1}, \mathrm{RWC}$, or $\Psi_{\mathrm{w}}$, but did reduce the intercepted PPF, as described by Caldas et al. (1997) for P. pubescens. Indeed, $S$. camporum paraheliotropic leaves showed higher $A$ rates when under the highest PPF (Figure 6G).

An alternative explanation for higher $A$ rates of paraheliotropic leaves is based on leaf structure. Our anatomical leaf analyses for both leaf types showed compact spongy parenchyma. A more compact leaf tissue could also represent increased photosynthetic capacity per unit leaf area. Chaves et al. (2002) suggested that compact leaf tissue permits better light interception and 
higher WUE. Thus, paraheliotropic leaf movement could permit the optimization of $\mathrm{CO}_{2}$ assimilation, except at 1600 h. At this time, WUE was significantly higher for vertical leaves because of lower transpiration rates, which seemed to have a weak relationship with the intensive reduction in leaf temperature. It is more reasonable to propose that this reduction in $\mathrm{T}_{1}$ was due to lower irradiance (at the end of the day), which was still parallel to paraheliotropic leaves, but perpendicular to diaheliotropic leaves, thereby leading to a higher $\mathrm{T}_{1}$.

One could still argue that leaf age, rather than leaf movement, determined the differences in gas exchange, since leaves from the bottom part of branches tend to be older. However, the diaheliotropic leaves that we studied were not more than five or six internodes from the completely expanded paraheliotropic leaves. Veneklaas and Boogaard (1994) observed two wheat cultivars with different leaf age-structures, but found no significant age-dependent differences in gas-exchange performance. Still, Constable and Rawson (1980) showed that the decline in $A$ rates in response to leaf age was associated with a reduction in $g_{s}$. However, lower $g_{s}$ did not fully explain the lower $A$ rates of diaheliotropic leaves.

Leaf angle adjustment of $S$. camporum could maintain higher gas exchange performance. Our data strongly indicate that $S$. camporum paraheliotropic leaf movement avoids an excessive irradiance load, with great supportive evidence from literature. Our anatomical leaf analysis also corroborates better light interception with increased photosynthetic capacity per unit leaf area. In conclusion, it seems that the paraheliotropic leaves of $S$. camporum have categorically higher $E$ and $g_{\text {s }}$, especially under maximum VPD. However, greater $E$ and $g_{\mathrm{s}} \operatorname{did}$ not assure lower $T_{1}$ for vertical leaves, and there was no direct evidence that $\mathrm{T}_{1}$ influenced carbon assimilation, $E$, or $g_{s}$. Thus, paraheliotropic leaf movement in $S$. camporum does not seem to be related to leaf temperature control, even in a stressful habitat such as the Brazilian cerrado.

Acknowledgements: We thank Alessandra Ike Coan and Patricia Fernandes Vendramini for writing assistance; Tatiane Maria Rodrigues for Photoshop assistance; and the Brazilian National Council for Scientific and Technological Development - CNPq (Proc. 405679/86) for financial support and for a Research Productivity Fellowship for S.R. Machado.

\section{REFERENCES}

Barrs HD, Weatherley PE (1962) A re-examination of the relative turgidity technique for estimating water deficits in leaves. Aust. J. Biol. Sci. 15:413-428.

Bielenberg DG, Miller JD, Berg VS (2003) Paraheliotropism in two Phaseolus species: combined effects of photon flux density and pulvinus temperature, and consequences for leaf gas exchange. Environ. Exp. Bot. 49:95-105.

Bukastsch F (1972) Bemerkungen zur dopplfärbung astrablau-safranin. Mikrokosmos 8:255.

Caldas LS, Lüttge U, Franco AC, Haridasan M (1997) Leaf heliotropism in Pterodon pubescens, a woody legume from the brasilian cerrado. Rev. Bras. Fisiol. Veg. 9:1-7.

Chaves MM, Pereira JS, Maroco J, Rodrigues ML, Ricardo CPP, Osório ML, Carvalho I, Faria T, Pinheiro C (2002) How plants cope with water stress in the field. Photosynthesis and growth. Ann. Bot. 89:907-916.

Constable GA, Rawson HM (1980) Effect of leaf position, expansion and age on photosynthesis, transpiration and water use of cotton. Aust. J. Plant Physiol. 7:89100.

Ferreira LG, Yoshioka H, Huete A, Sano EE (2003) Seasonal landscape and spectral vegetation index dynamics in the Brazilian cerrado: an analysis within the large-scale biosphere-atmosphere experiment in Amazônia (LBA). Rem. Sens. Environ. 87:534-550.

Forseth IN, Ehleringer JR (1982) Ecophysiology of two solar tracking desert winter annuals. II. Leaf movements, water relations and microclimate. Oecologia 54:41-49.

Gerrits PO (1991) The application of glycol methacrylate in histotechnology: some fundamental principles. Groningen, Netherlands.

Grantz DA (1990) Plant response to humidity. Plant Cell Environ. 13:667-679.

Jensen WA (1962) Botanical histochemistry: principles and practice. W.H. Freeman, San Francisco.

Johansen DA (1940) Plant microtechnique McGraw-Hill Book Co, New York.

Kaufmann M (1968) Evaluation of the pressure chamber method for measurement of water stress in citrus. Proc. Am. Soc. Hort. Sci. 93:186-198.

Koller D (1986) The control of leaf orientation by light. Photochem. Photobiol. 44:819-826. 
Koller D (1990) Light-driven leaf movement. Plant Cell Environ. 13:615-632.

Liu CC, Welham CVJ, Zhang XQ, Wang RQ (2007) Leaflet movement of Robinia pseudoacacia in response to a changing light environment. J. Integr. Plant Biol. 49:419-424.

Machado SR (1991) Morfologia e anatomia dos órgãos vegetativos de Styrax camporum Pohl. (Styracaceae) em desenvolvimento. São Paulo, University of São Paulo. PhD thesis.

Machado SR, Angyalossy-Alfonso V, Morretes BL (1997) Comparative wood anatomy of root and stem in Syrax camporum (Styracaceae). IAWA Bull. J. 18:13-25.

Meinzer FC, Goldstein G, Franco AC, Bustamante M, Igler E, Jackson P, Caldas L, Rundel PW (1999) Atmospheric and hydraulic limitations on transpiration in Brazilian cerrado woody species. Funct. Ecol. 13:273-282.

O’Brien TP, Feder N, Mccully ME (1964) Polychromatic staining of plant cell walls by toluidine blue. Protoplasma 59:368-373.

Oliveira PS, Marquis RJ (2002) The cerrados of Brazil: ecology and natural history of a neotropical savanna. Columbia University Press, New York.

Pastenes C, Pimentel P, Lillo J (2005) Leaf movements and photoinhibition in relation to water stress in fieldgrown beans. J. Exp. Bot. 56:425-433.

Prado CHBA, Wenhui Z, Rojas MHC, Souza GM (2004) Seasonal leaf gas exchange and water potential in a woody cerrado species community. Braz. J. Plant Physiol. 16:7-16.
Prior LD, Eamus D, Duff GA (1997) Seasonal and diurnal patterns of carbon assimilation, stomatal conductance, and leaf water potential in Eucalyptus tetrodonta Saplings in a wet-dry savanna. Aust. J. Bot. 45:241-258.

Rodrigues TM, Machado SR (2006) Anatomia comparada do pulvino primário de leguminosas com diferentes velocidades de movimento foliar. Rev. Bras. Bot 29:709-720.

Sass JE (1951) Botanical microtechnique. Iowa State University Press, Ames.

Schadel WE, Dickson WC (1979) Leaf anatomy and venation patterns of the Styracaceae. J. Arnold Arbor. 60:8-25.

Schulze ED, Hall AE (1982) Stomatal responses, water loss and $\mathrm{CO}_{2}$ assimilation rates of plants in contrasting environments. In: Lange OL, Nobel PS, Osmond CB, Ziegler H (eds), Encyclopedia of Plant Physiology, pp.181-230. Springer-Verlag, Heidelberg.

Sheriff DW, Ludlow MM (1985) Diaheliotropic responses of leaves of Macroptilium atropurpureum cv. Siratro. Aust. J. Plant Physiol. 12:151-171.

Veneklaas E, Boogaard RVD (1994) Leaf age-structure effects on plant water use and photosynthesis of two wheat cultivars. New Phytol. 128:331-337.

Vogelmann TC, Björn LO (1983) Response to directional light by leaves of a sun-tracking lupine (Lupinus succulentus). Physiol. Plant. 59:533-538.

Von Caemmerer S, Farquhar GD (1981) Some relationships between the biochemistry of photosynthesis and the gas exchange of leaves. Planta 153:376-387. 